\title{
New Perspectives on Turkey roundtable on the COVID-19 pandemic : prospects for the international political economic order in the post-pandemic world
}

Ayşe Buğra, Refet Gürkaynak, Çağlar Keyder, Ravi Arvind Palat, and Şevket Pamuk

\section{Introduction}

The pandemic triggered by the novel coronavirus has not only created a global public health emergency, it has also had widespread and deep consequences in social relations throughout the world. The COVID-19 pandemic forces social scientists to reflect on a range of issues from gender relations and science and technology to the international political and economic order and the environment. As the editors of New Perspectives on Turkey, we decided to assemble a virtual roundtable to reflect on the challenges it poses to the international political economic system. We invited professors Ayşe Buğra, Refet Gürkaynak, Çağlar Keyder, Ravi Arvind Palat, and Şevket Pamuk to share their views on these challenges and are grateful to them for contributing to this discussion.

NPT Editors (Biray Kolluoğlu, Deniz Yükseker, and Evren M. Dinçer*): Prof. Palat, we would like to start with you. In three to six months from now and after its demise, what do you think will be the most important impact of the COVID-19 pandemic on the international political and economic order? Ravi Arvind Palat: The COVID-19 pandemic is not an event but an ongoing process and no balanced assessment of its impact within a short time horizon is possible. There are some certainties, however: it will cause an

Ayşe Buğra, Social Policy Forum, Professor Emerita, Boğaziçi University, bugray@boun.edu.tr.

Refet Gürkaynak, Department of Economics, Bilkent University, refet@bilkent.edu.tr.

Çağlar Keyder, Department of Sociology, Binghamton University, keyder@binghamton.edu.

Ravi Arvind Palat, Department of Sociology, Binghamton University, palat@binghamton.edu.

Şevket Pamuk, Ataturk Institute, Boğaziçi University, pamuk@boun.edu.tr.

*Corresponding Author: Evren M. Dinçer, Department of Political Science and International Relations, Abdullah Gül University, evren.m.dincer@gmail.com. 
unprecedented economic crisis: the Great Depression, the two World Wars, the 2008 financial crisis all caused economic disruptions but none led to worldwide restrictions on mobility at the same time; unemployment spread gradually over the course of the Great Depression - now in just six weeks, unemployment in the United States alone topped 30 million and 140 million in India; the First World War was primarily restricted to Europe; the Second World War did not affect the American continent and much of Africa; "emerging markets" grew during the 2008 financial crisis.

This pandemic has affected the entire world. Lockdowns deprive people of income; demand craters except for essential commodities; tax revenues plummet; supply chains rupture; and oil prices turn negative. Closure of schools, restaurants, and hotels means crops rot in the fields even as charities are overburdened with demands for food. The World Trade Organization estimates a decline global trade between 13 and 30 percent in 2020 and this may well be an underestimate.

In an unequal world-economy, central banks of high-income economies have intervened massively to provide liquidity, an option unavailable to most low- and middle-income economies. In crisis situations, capital flows to safe destinations. Since January 2020, over $\$ 100$ billion have flowed out from the emerging markets, $\$ 83$ billion in March alone. Lockdowns have reduced remittances from the diaspora to low- and middle-income states to a trickle. From January to March, portfolio investment in these economies has declined by 70 percent compared to the same period in 2019. Unsurprisingly, the value of their currencies has plunged.

These factors have important implications for the world financial structure. The International Monetary Fund (IMF) is the only institution capable of creating liquidity on a scale sufficient to revive the world-economy. While economies with strong international reserve currencies can largely fend for themselves, low- and middle-income countries cannot. To provide them with liquidity, the IMF needs to issue Special Drawing Rights (SDRs), perhaps of the order of \$1-2 trillion as Jayati Ghosh suggests, an option opposed only by India and the US! Additionally, and especially given the collapse of their currencies, their debt should be restructured or forgiven.

Within states, racial and ethnic minorities have been disproportionately impacted by the pandemic. They are the low-waged workers staffing essential services: stocking grocery stores, harvesting crops, slaughtering animals, and working in sanitation and transport. They are the ones living in slums and favelas, least able to practice physical distancing at home or on the public transport systems they must rely on to go to work. Migrant camps in Europe and the United States with cramped living conditions and stretched health services suffer untold misery. So too with prisons, and of course Gaza. 
European Union (EU) states depend on North African and Eastern European migrants for two-thirds of the low-waged, back-breaking harvesting tasks and travel restrictions have effectively halted their movements. In the United States, migrant labor has been hard hit by the virus, severing food supply chains, prompting President Donald Trump to issue executive orders to open virus-hit abattoirs! In India, the lockdown of the economy with only a few hours' notice compelled migrant workers to walk often hundreds of kilometers home as they were deprived of income and shelter and left crops unharvested. The globalization of food trade - tripling in value between 2000 and 2016 - also means that many low- and middle-income states lack food sovereignty as their producers could not compete with subsidized agricultural imports from North America and the European Union. This makes a restructuring of their debt all the more critical.

The reluctance of northern European states to help southern Europe cope with the pandemic's costs severely undermines the European project and it remains to be seen how that will unfold. Israel has used world preoccupation with the virus to annex the West Bank. In the midst of the pandemic, Trump froze funding to the World Health Organization, compounding problems for poor states and delegitimizing US claims to global leadership.

The pandemic has witnessed a brazen usurpation of power by governments from powers to rule by decree and suspension of parliaments as long as the emergency lasts to more "modest" bans on movement and censorship of the media. Troublingly, methods of contact tracing to limit the spread of the virus confers vast surveillance powers on the government. Even if these powers are curtailed, data-mining the material obtained can reveal patterns of behavior, circles of contacts of opposition figures, and other sensitive information. Hence, even though it is impossible to provide an adequate balance sheet of the pandemic's impact, there are very troubling issues to concern us now and in the near future.

NPT Editors: Prof. Buğra, what is your opinion on the effects of the COVID-19 crisis, especially on its immediate impact?

Ayşe Buğra: One of the most important immediate effects of the COVID-19 pandemic was to introduce an immense uncertainty in people's lives throughout the world. We live in a totally new state of not knowing what life will be like in the months to come or when we will return to our "normal" lives. Still, we can predict with some confidence that there will be a deep recession which will affect almost all countries, and whether the recovery will be quick or slow will depend on the duration of the pandemic. We also know that setting the stage for a strong recovery depends on taking the right measures to combat recession and the attempts at policy formulation should begin now, perhaps by considering different scenarios based on how long it will take before the shutdown ends. 
But if we think about the "normal" state of the world before the pandemic, another question emerges: do we want the world to go back to that normal state? This is an important question because now, with our lives totally dominated by the pandemic and the information we receive on its effect on people throughout the world, we have a better idea than before about what is wrong with our societies and with the nature of coexistence in a globalized world. The questions about the international economic and political order which emerge in the context of the pandemic might be considered as an important aspect of the impact of what happened to "us" as people living in a globalized world.

We knew, of course, that our globalized world is characterized by the contradictory dynamics of economic growth and precarity, integration and inequality. But with "quarantine," "shutdown," "workplace closure," and "social distancing" as terms which now dominate the news, one is forced to think about where and how hundreds of millions of people live and what these terms mean in light of their lives. Looking at the World Employment Social Outlook 2019 of the International Labour Organization (ILO) now, with the terms COVID-19 introduced in our lives, facts and figures such as "61 percent of the global work force are in informal employment," "one in four persons employed in low and middle income countries live in extreme or moderate poverty," or " 55 percent of the global population do not enjoy any social protection" acquire a chilling reality. We then understand better the meaning of some of the passages in the report, such as those where it is mentioned that where social protection is absent pursuing any kind of economic activity is essential for survival, and unemployment rates are the lowest in low-income countries where employment is typically informal. Where informal employment and working poverty constitute the reality of the lives of millions of people, not going to work often means starvation. The risk of infection does not change this fact and staying home is simply not an option. Then there is the question of "homes" where people are expected to stay. The global estimate for homeless people is over 100 million and well over a billion people lack adequate housing; they live in overcrowded dwellings, without access to clean water and basic sanitation services such as toilets or latrines. Among the facts and figures given in the context of the UN Sustainable Development Goals, we read that "each day, nearly 1,000 children die due to preventable water and sanitation-related diarrheal diseases."

All these facts and figures were widely available in pre-COVID-19 days, but they now come home with a new concern about containing and combatting the pandemic. As we obediently follow the instructions to work from home, wash our hands carefully, and disinfect our delivered purchases, we might remember Mike Davis's Planet of Slums, published in 2004, and remember also that poverty is now a more urban problem than it was ever before. This means 
that protection against the virus spreading from unfamiliar quarters is a problem that must be faced in a globalized world. How much isolation would be necessary to avoid the public health hazard created by the homeless and the destitute who are no longer in isolated villages or communities but live in overcrowded cities as part of the cheap labor force engaged in economic activity?

The dimensions are of course different, but neither homelessness nor inadequate housing nor the absence of social protection are problems peculiar to the global South. The difference between precarious jobs and "decent work" opportunities which the ILO calls for is not only relevant for low-income countries. In the rich countries of the North, too, employment is precarious for many people and with the new gig economy, in which workers are classified as self-employed in occupations which traditionally offered social protection, the decision to stay home might involve a difficult choice between the loss of all income and the possibility of getting infected.

Beyond work and employment, the pandemic has also revealed the limits of social risk protection in rich countries. The pathetic state of the American health system with 27.5 million people without health insurance has long been known and debated, but the title of a recent article which appeared in the Guardian brings a new perspective to the debate: "Millions of uninsured Americans like me are a coronavirus bomb." The article's message is that the potential spread of the virus in the US is great given the significant number of uninsured people who will not see a doctor when they are sick. The writer also mentions that the last time he saw a doctor was in 2013 when he broke his arm. The doctor put his arm in a sling and he had to pay $\$ 4,000$.

Problems of health care are not unique to the US, where the disregard for the idea that access to health services is a social right is stronger than elsewhere; deviations from this idea can also be observed in many other countries. There are also other problems of social risk protection which exist in many rich countries. For example, one of the problems that COVID-19 has exposed is those of elderly care in "social" Europe. Population aging has been long debated in Europe where public care for the elderly is better funded and more adequate than in most other countries. Nevertheless, in the midst of the flood of information on the pandemic there were stories about not only the deaths but the circumstances of death of many elderly people in old age homes in Europe and also Canada, a country with a good system of social protection and care.

The response to what the pandemic has revealed will be varied and will reflect different political positions. But it is not without reason that nowadays many people remember Camus's Plague and the following quotation from the novel: "That is an idea which may make some people smile, but the only means of fighting a plague is common decency." Common decency may also be needed 
when the lessons so far learned from the pandemic are interpreted and used in politics and policy in the post-pandemic world.

NPT Editors: Prof. Pamuk, how would you reflect on the same question? And, as a historian, in what ways is this pandemic different from previous ones in your opinion?

Şevket Pamuk: As I write at the end of April 2020, the first wave of the COVID-19 pandemic is flattening in many countries. However, there remains a great deal of uncertainty about the duration of the pandemic as well as its long-term health and economic impact. We do not know whether there will be new waves of the virus later this year or the next. We do not know how quick or slow the economic recovery will be. Until an effective vaccine is made available around the world, these uncertainties are likely to persist. The longer it takes for a vaccine to come to the rescue, the heavier will be the health and economic consequences of the pandemic and its impact on the international political and economic system.

In addition to a global recession, many people expect a pullback from globalization in the years ahead because of the problems the pandemic has raised for global value chains and the national security concerns in many countries. In what follows, however, I argue that the most important consequence of the pandemic will be to increase the inequalities both within and between countries. The longer the pandemic persists, the larger and more uneven will be its health and economic consequences. The growing inequalities caused by the pandemic might weigh on the international political and economic system for years to come.

I have studied the economic impact and long-term consequences of pandemics in history on different parts of Europe and the Middle East. The Justinian plague and the Black Death pandemics did not lead to the same long-term consequences everywhere they visited. Perhaps the most important insight from studying their history is that the impact of the pandemics depended on the interaction between the disease and societies, economic structures, institutions, struggles between different groups, and of course state policies. Even though states had limited capacity in those earlier eras, what they did still mattered. In short, one important takeaway from the pandemics of the past is that their long-term impact was uneven across different societies.

The impact of the current pandemic is likely to be uneven within countries. There is growing evidence that the COVID-19 pandemic is having a larger impact on lower-income groups. Those who lost their jobs and those who have to go out and earn an income every day have a more difficult time protecting themselves. Moreover, healthcare systems and government programs are often not able to support them adequately.

It is also likely that the impact of the COVID-19 pandemic will not be the same in different countries. The more developed countries in East Asia and 
Europe have older populations. As a result, they have been affected more harshly by the virus and experienced more deaths so far. However, these societies also have more developed health care systems, more resources, and generally better institutions to deal with the pandemic. States in developed countries are generally stronger. In recent weeks, they were able to put together monetary and fiscal packages whose sizes have never been seen before in peacetime. These unprecedented measures are likely to increase the debt burden at every level - households, firms, and the state - but the developed economies have a much better chance of dealing with the debt problem in the longer term.

In developing countries, in contrast, the population is younger but healthcare systems are poorer. The economies are weaker and the capacities of the states are low. In addition, while most developed countries spend, borrow, and pay their debts in their own currency printed by their own central bank, developing countries will need to secure, and in most cases borrow, dollars and euros to pay their debts. In short, developing countries will not even come close to matching the policies of the developed countries in response to the pandemic. If a vaccine does not become available soon, the loss of lives, poverty, and human suffering are likely to be much more severe in developing countries.

The COVID-19 pandemic is likely to exacerbate existing inequalities around the world by disproportionately impacting the poor. The longer the pandemic persists, the larger and possibly more uneven will be the health and economic consequences within countries and between countries. The international political and economic system is already hampered by large inequalities. The uneven and large impact of the pandemic would make it weaker and more fragile. If not addressed, the growing inequalities within and between countries may also lead to a political backlash against the existing system.

NPT Editors: Prof. Keyder, what is your opinion on the same question? Also, we would like to ask you to reflect on possible unanticipated consequences of the crisis.

Çağlar Keyder: Economic crisis following the great lockdown seems inevitable and is likely to last longer than imagined. It is developing in the wake of a long-term stagnation marked by growing insecurity for the working masses. Not only has life become more uncertain, but a strict regime of market supremacy has created income and wealth inequalities not experienced since the First World War. Shrinking middle classes have been working harder and living in anxiety to protect an increasingly elusive standard of life; their children's life chances now fall short of matching those of their parents'. At the same time, the vast majority of workers are subject to instability of employment and 
wages that have been stagnating over several decades. Now, with the real threat of COVID-19, the world has experienced the greatest shutting down of the economy in history, with perhaps the better part of the global labor force affected in some measure. Only a small minority of the workers now at home will receive adequate compensation while unemployed; some of them have been furloughed, while most of the rest are made redundant with no hope of regaining their former position. The question is whether they will ever find paid employment again. The common wisdom is that even in the case of a quick "opening" of the economy, a large portion of the jobs will not return - fewer cafes and restaurants will reopen, many gig opportunities will dry up, there is a surplus of completed construction now empty, and tourism will surely suffer more than most sectors. With shrinking incomes and declining effective demand, the whole economy will stagnate. All the curlicues appended to the urban economy of great cities that provide millions with wages to pursue precarious lives may perish for good. As societies seem wedded to the notion that livelihood should depend on employment, householding on the margins of the market economy may become an attractive option. But resources (mainly land) for such self-sufficiency are available only to a minority, and mostly in the South.

The crisis in employment implies a problem of livelihood for the vast majority, but it does not necessarily signal total economic collapse. In fact, the prospects for the largest companies have been looking positive as they strengthen their market dominance. It seems likely that the skewed distribution of income and wealth will become even more polarized as the pandemic wanes. This concentration of rewards foreshadows an economy that caters exclusively to the very wealthy, while the working poor wait for the trickle to seep down. Of course, such a state of affairs is not exactly new. For all the physical and mental damage it causes, polarized income and wealth distribution does not always lead to passionate protest; but insecurity often does. In the absence of secure employment, the impending problem facing societies will be material security: the masses will need and ask for protection and support, in a quest for health, subsistence, and the basic needs of shelter and education. In the absence of a strong economy and secure employment, these can only be provided through redistribution - and by states strong enough to raise their tax revenue despite opposition by the owners of the means of production.

The trend toward stronger states and more authoritarian government and rule by decree is already visible; the demand to redress the circumstances of precarious lives will only reinforce the tendency. However, strong states come in different flavors, and it is here that we are likely to witness important divergence: European states, strong in their ability to mobilize resources and create consent, have entrenched traditions of welfare. They are in a better 
position to respond to the search for security with genuine measures guaranteeing health and needs, and are most likely to evolve toward some form of meaningful universal basic income. In many other societies, however, solidarities have not been nurtured, the political culture glorifies dependence on the market for livelihoods, and the most recent wave of populism has aggravated divisions in society with undue emphasis on clashing identities. With such a legacy, the US and most states in the rest of the world are prone to engage in measures that are more authoritarian in order to keep their needy populations on life support. Certainly, nationalist rhetoric and mercantilist policy will peak everywhere, but state capacities will evolve differently and popular demands will result in diverse outcomes. So, rather than the hegemonic contest between the US and China, it will be the nature of the state-society relationship, and the degree and mode of redistribution, that will color the diverse fortunes of the insecure populations of the globe.

NPT Editors: Prof. Gürkaynak, what would your response be to the same question?

Refet Gürkaynak: Politics and economics, as ever, will be intertwined. I am sure there will be deep, far-reaching effects in international relations, class relations, and how we organize as societies, but I have little insight into which new paths will be taken. Let me comment on narrower issues that I see as being obvious.

There will be mountains of debt to reckon with. Households are running down savings, firms are burning cash, governments are increasing spending at a time of lower revenues. Aggregate debt shocks always culminate in private debt turning into government debt. This time will be no different. It is important to see that this is not just about money. Production has decreased; trying to keep consumption above subsistence requires dipping into savings and borrowing to use other peoples' savings. The ensuing debt will not be easy to manage.

Distribution of the debt repayment burden will be a first-order problem. Running down debt, including defaulting on it, requires distributional choices. These are never easy, and they are especially difficult when output is below normal and growing out of debt problems is not an option. Default makes the lenders pay for debt. It also means defaulted borrowers will not be able to borrow, at least for a while. Monetizing the debt usually inflates it away and inflation also has distributional consequences. Having budget surpluses mean taxing more and decreasing services, neither of which are easy in economies with output gaps.

There will be stronger demand for formal social safety nets. Informal social safety nets, such as family and friends, are insufficient when the shock is aggregate, large, and persistent. These kinds of safety nets often work well when there is an idiosyncratic shock, such as someone becoming ill or 
unemployed. But when the effect is widely cast, deeply negative, and longlasting, often the people who would otherwise insure each other all need help. This is when public transfers in the form of a formal social safety system is truly needed. That need has become obvious, even in the US, and more people around the world are looking for assistance from their governments for basic health and subsistence. This may lead to stronger and less ad hoc social security schemes, which would be welcome, but may also lead to more paternalism and authoritarian governance in return for services that are presented as handouts.

Many countries will find the simultaneous debt sustainability and social security demands insurmountable. This is already clear and underlies the calls by and for the poorest countries regarding debt forgiveness. It will not be a problem for the poorest countries only. Global resources have shrunk as a result of the global pandemic. Simultaneously trying to repay debt and heeding calls for increased social services out of lower income will be impossible for many countries.

There will be push-back against globalization. This is a separate issue from the debt, social security, and distributional concerns. Just-in-time production with production chains spanning many countries have taken a hit. More importantly, it became clear that some necessities, such as personal protective equipment for healthcare givers and, increasingly, staple foods may not be as tradable just when they are needed most. This realization will lead more countries to protect their own "strategic" sectors or at least try to have larger reserves of these goods. Firms trying to rein in their supply chains and governments trying to have domestic production of basic necessities will likely combine into a reduction in trade.

NPT Editors: Thank you for this thought-provoking first round of answers. A deep and prolonged worldwide depression and a global trend toward stronger states appear as two common threads in each response. However, you also highlight significant but different aspects of the crisis.

Comparing the current pandemic with previous ones, Prof. Pamuk stresses the uneven impact of the COVID-19 pandemic within and between states. Questioning the need and legitimacy of a potential return to the "normal" prior to the crisis, Prof. Buğra draws attention to major failures of welfare systems in the West, particularly in the US, highlighting the hitherto unseen destructive employment effects of the crisis. Prof. Keyder points toward two seemingly contrasting trends as outcomes of the crisis: increasing rates of capital concentration favoring large corporations in the North and a potential return to householding for subsistence purposes in the South. Emphasizing the unprecedented nature of the current crisis because of its truly global and simultaneous reach as well as its extremely destructive impact in such a short time span, 
Prof. Palat claims the crisis will force a recasting of the North-South divide and that debt restructuring will emerge as a major political issue. Prof. Palat also argues that the immensely different nature of responses of governments and central banks across the world already shows the signs of a greater divergence. Along the same lines, Prof. Gürkaynak calls our attention to previously unimaginable levels of debt, but perhaps differing from Prof. Palat, he points out that debt will be an issue to reckon with for households, corporations, states, and supra-state institutions across the world and not just in the South. Prof. Gürkaynak also anticipates a large-scale demand for more social safety nets.

In the second round, we would appreciate it if you could reflect upon one or more of the themes we summarize above. But we would also like to ask separate questions to each contributor. Prof. Pamuk, we would like to start with you. You remind us that historically the uneven impact of pandemics "depended on the interaction between the disease and societies, economic structures, institutions, struggles between different groups, and of course state policies." Can you talk a bit more about state policies in the face of epidemics and their differential consequences?

Şevket Pamuk: I would like to build on my earlier remarks and emphasize the absence so far of international cooperation in response to the pandemic. I argue that the absence of or weak international cooperation will not only add to the health and economic impact of the pandemic but is also likely to make its impact on the poor in the developing countries deeper and stronger.

Some years from now, when more detailed accounts of the pandemic become available, historians will write that governments on both sides of the Atlantic were caught unprepared, and that many of them remained in disarray and responded very late to the pandemic. Equally striking has been the weakness if not complete absence of international cooperation in response of the pandemic. While Europe is having a difficult time reconciling the diverging positions of the north and the south of the continent, the United States government has been actively trying to undermine the very global order it has helped construct since the end of the Second World War.

This pattern shows once again that the key players in the global system and in the emergence of a united response to the pandemic are not the global institutions such as the World Trade Organization and the IMF but the leading states still. International cooperation is likely to break down without the active involvement of the leading states. Without such cooperation, there is always the risk of repeating the mistakes of the interwar era when the global economy remained in depression and, in the absence of a dominant power to coordinate and lead such cooperation, each of the leading states tried to protect its own interests at the expense of the others. 
Because of its still powerful position, the role the United States will play in the international response to the pandemic matters a great deal. For this reason, the outcome of the elections in the United States in November are very important. Whether the United States will emerge from the elections with an administration that will better address its urgent domestic problems and is also more willing to engage in international cooperation will be watched closely around the world.

In the responses of the different governments to the pandemic so far, it is clear that there is a big difference between good government policy and bad government policy, and good policies can make a difference. At the same time, as I emphasized in my first-round remarks, major contrasts are emerging between the responses of the developed and the developing countries. In terms of the economic policy response, the developed countries have quickly shed their past reservations not only about the size and extent of monetary interventions but also about the size of fiscal packages. Their central banks are willing, in effect, to print all the money it takes to finance or monetize the fiscal packages. With some variation, the parliaments, governments, and central banks in the developed countries have adopted a "now is the time" attitude. It appears that they are also willing to continue with even more extensive monetary and fiscal interventions, if necessary, in the months ahead. At the moment, addressing whatever longer-term problems these unprecedented policies may create have been postponed to the future.

The contrasts with the developing countries are striking. So far, the impact of the pandemic on Africa has been limited but the virus has been spreading in South Asia and Latin America. In addressing the health and economic impact of the pandemic, the governments of developing countries, many of them already burdened with large international debt, have been able to mobilize only a tiny fraction of the resources that are being marshaled in the developed countries. Because a large part of their past borrowing and debt has been in foreign currency, financing their growing deficits and debt by printing their own currency is not going to be an effective response for the developing countries. As a result, they have been much more cautious in their response to the rapid decline in economic activity and incomes even though safety nets, welfare programs, and unemployment benefits are already weak or absent in the developing countries.

The magnitude of the funds being made available to the developing countries by the IMF and other international agencies is only a tiny fraction of the funds being deployed by the developed countries to address their own economic problems at home. Much larger sums may become necessary depending upon the spread of the virus and the duration of the pandemic in developing countries. If the pandemic continues to spread and if an effective 
vaccine does not become available soon, the impact on the poor is likely to grow rapidly. There are already indications that even if an effective vaccine is found, developed countries will be the first to use it. The vaccine may become available only at high cost to developing countries.

International cooperation is important in dealing with the pandemic and its impact among the poor in developing countries. It remains to been seen, however, to what extent such cooperation will materialize or whether the global order will slide toward growing competition between the US and China in the months and years ahead.

NPT Editors: Prof. Gürkaynak points to the conundrum of an increasing demand for formal social safety nets while the financial means for doing so are absent. Prof. Keyder also mentions that there will be demands for redistribution. Professor Buğra, you note the already existing poverty, precariousness, and homelessness in the South as well as problems of social risk protection in the North. Following from these observations, what new forms of welfare provision can be expected to emerge or what forms are to become more prevalent in the post-pandemic period?

Ayşe Buğra: As we try to imagine what the post-pandemic world might look like, it becomes tempting to remember the post-Second World War transformations through which the nineteenth-century global economy was replaced by a new world order. I tend to think that this analogy calls us to consider the difference between the terms "global" and "international." The terms "global" and "globalization" entered our terminology and dominated social analysis with late twentieth-century economic globalization. We then began to use the term "global" where we used the term "international" (as in the period when I was a student). I think the difference is not without significance because it is closely related to the changing perceptions of the nation-state in a period when concerns about supra-national dynamics have come to dominate approaches to politics and policy.

It now seems possible to think that the pandemic might be instrumental in the advent of a new world order with more room for institutional and policy diversity, an order where the nation-states once again become important actors. This might have unpleasant political consequences, which include the strengthening of already present populist nationalisms increasingly deviating from the norms of liberal democracy and the rule of law. But it might also mean more room for political interventions against the commodification of land, labor, and money which, at present, has devastating effects on people's lives and livelihoods as well as on the natural environment.

Where policy intervention by nation-state is not limited by the logic of the global market economy, it is possible to think of welfare provision in relation to industrial and agricultural policy choices and the terms of employment in 
industry and agriculture. Without the now overwhelming fear of capital flight and the objective of attracting foreign capital, employment policy would not be limited by concerns about the place of the national economy in "global commodity chains," markets for agricultural production could cease to be subservient to organization by agribusiness, peasant agriculture would not be perceived solely as an archaic form bound to disappear, and urban development could be approached in a way that problematizes the current nightmarish patterns of urbanization. At the same time, priorities in government spending could be set by acknowledging that the trends toward privatization in health, education, or social care provision might not be compatible with the notion of social rights.

In such a setting, social policy would form an integral part of an economy which, in Polanyean terms, is reembedded in society. This does not mean that unemployment and working poverty would disappear and social assistance would lose its significance. In fact, income support policies of different types are likely to be important in the post-pandemic world, where unemployment and poverty will rise at least in the short term, no matter what kind of policy interventions emerge. In the long term, too, these income support policies must be an essential component of social policy if human depravation and the threat of social exclusion facing some people in all societies are to be prevented. Whether they will be the centerpiece of the attempts to manage poverty and insecurity or complements to an economy where the creation of decent world opportunities and providing social security to all are key objectives would be determined by the outcomes of political choices.

Of course, the possible emergence of reembedded national economies can take different forms, including the highly inefficient and unequal ones where poverty and inequality could become even deeper than they are now. Voluntary associations and the logic of charity, which have become an integral part of the national and global response to human deprivation through economic globalization, might still continue to play an important role with their problematic relationship with social rights. Nevertheless, if I pursue my Polanyean line of thinking further, I could perhaps say that after the pandemic we will be living in a world where politics is more important than it has been in the context of economic globalization in determining how people work and live, and the extent to which inequality is tolerated or problematized. Political struggles or negotiations within each country may have more impact on life in society, and the international community would be in a position to accept or critically respond to the outcome of these struggles or negotiations. In a context where the claims about the "natural," "inevitable," or "without alternative" character of the global market economy cease to be persuasive, the international 
response and criticism with their channels of expression and accompanying mechanisms of sanction, too, would be political in nature.

I write these lines with the awareness that there are strong interests which would effectively push for a return to business as usual as soon as the pandemic is controlled. At the end of the Second World War, the world did not return to business as usual and a new world order was established. We are yet to see how relevant the analogy is.

NPT Editors: Professor Keyder, saying that unemployment will lead to a livelihood problem, you argue that householding on the margins of the market economy might be an option for some in the South. Can you please expand on that? How likely is it and where? We would also like you to detail your prediction that mercantilist policy will peak everywhere. In which areas would you particularly expect that to happen?

Çağlar Keyder: Freefall in global goods trade, reshoring of supply chains, shrinking flows of transnational capital - these are some of the headlines pointing to continuing disruption of what was heralded as globalization. Global economic integration through the increasing subdivision of production processes was meant to augment produced value, integrate large numbers of new workers into capitalist production, and make available creature comforts to heretofore excluded populations. The privilege of being exploited by capital was costly but it yielded returns. While it lasted, globalization proved its mettle; but, as it was meant to be doing, it also created huge disparities in material returns, leading to extreme degrees of income and wealth polarization, between and within nations.

The current disruption does not inconvenience the few at the top, with billionaires adding to their wealth. As smaller companies and shops in the services sector suffer the consequences of declining demand there is a concentration of consumer expenditure and government rescue funds at the top. The middle class, roughly those who have not been made redundant or furloughed and are working from home, are perhaps suffering from some shrinkage in salaries that they were forced to accept. For the bottom layers, however, the trickle has dried up. The predicament of the precariat and the workers is dismal: there is massive unemployment, reaching a third of the labor force in some countries, which will likely persist into the post-COVID period. These rates also portend declining wages for those fortunate enough to retain their jobs.

The Turkish government has announced a small project aiming to distribute public land to new farmers, presumably targeting the newly unemployed that might return to the countryside. This initiative signals the recognition that the urban-rural division is fluid, as suggested by large numbers of part-time dwellers in the countryside who return when employment dries 
up in the city or when farming tasks require additional labor. Of course, relative self-sufficiency in the household is more attainable when access to land is available and a certain degree of decommodification becomes feasible.

For most societies, such a policy of self-help, based on the assumption of the possibility of a return to the countryside, is unrealistic: the core demand for basic needs - food, health, shelter, and education for the young - will have to be addressed to the state. If unemployment and loss of income become more permanent, even the most authoritarian regimes will find it self-defeating to resort to neoliberal formulas in response. In the absence of massive funding for social policy, which is beyond the capacity of most governments, employment creation independent of the circuits of global capital will remain the only viable policy. Employment creation presumes the rejection of the logic of the global marketplace by creating barriers against the penetration of this logic into the national economy. This choice signals submission to the perennial siren song of protectionism which will be popular and seen as progressive if and when it engages in decommodifying the production and provisioning of basic needs. However, protectionism is likely to extend into import substitution and export promotion, with mercantilist competition as the inevitable result.

What may derail this scenario that threatens to reproduce the steps leading to the 1930s debacle? The only plausible answer is a power that succeeds in proposing a route out of the quagmire that convinces and elicits the consent of other players. Clearly, such a power has not existed for some time. COVID has brutally highlighted the detritus of the interregnum in the American theatre where the old hegemon fights its domestic feuds. China, as the presumed challenger, is embroiled in its domestic and near-abroad tussles. Aside from a blueprint for commerce, it seems to entertain no willingness to offer to the rest of the world a project envisaging peace and prosperity. The European Union is mired in the old debates of how much power should be conceded to Brussels. Perhaps, some argue, a series of regional arrangements - satrapies that may count on sufficient authority to ward off the threat of mercantilist anarchy in their geographies - may emerge as a solution. While conceivable in the case of the immediate environs of both China and the EU (and possible with the revival of the Monroe doctrine in America) this solution may paradoxically condemn territories outside of the ambit of the regional hegemons - the "intermediate region" - to conflict, uncertainty, and continuing belligerence. I am, of course, thinking of Turkey.

NPT Editors: Prof. Gürkaynak predicts that a pushback against globalization is to be expected. Professor Palat, can we ask you to reflect on that statement? For instance, in which sectors should we expect domestic production to seek to replace global supply chains? Or, in which sectors might global 
production networks be more resilient? Especially, what could become of the food import dependency in many countries in the South?

Ravi Arvind Palat: The coronavirus pandemic has disrupted the worldwide movement of peoples and goods with a velocity unparalleled in history. Supply chains everywhere have been severely strained as anxious populations hoard food and even toilet paper; the lockdown to mitigate the spread of infection has reduced transportation, increased freight costs, and even briefly turned oil prices negative. Shortages of personal protection equipment (PPE) underlined the consequences of deindustrialization for high-income economies and globalization caused food prices to rise in the global South as their currencies plummeted precipitously.

Pressure on states to protect themselves through greater self-sufficiency, and especially to regain food sovereignty, has spurred expectations of a process of deglobalization. Such anticipations derive from the crisis of hegemonic transition a century ago - when world trade collapsed during the First World War and the years that followed: "world capitalism retreated into the igloos of its nation-state economies and their associated empires," in Eric Hobsbawm's memorable words.

Yet, that retreat happened because war and the subsequent "Great Depression" created a sense of national solidarity as massive white working-class movements demanded social justice for themselves within imperial trading blocs! British wartime rationing in the 1940s provide a more equitable distribution of food. Over that decade, the life expectancy of women rose by seven years and of men by 6.5 years. Notably, as Hobsbawm highlighted, this withdrawal did nothing for the colonies: three million died in Bengal alone in the 1943 famine as grain continued to be exported.

No comparable cross-class solidarity exists today because deindustrialization weakened the working class and class privilege refracts the pandemic's economic impact. The Thai king's seclusion with twenty concubines in a Swiss resort sharply silhouettes the plight of millions forced to toil in close quarters. Between mid-March and mid-April, when twenty-six million people filed for unemployment in the United States, food lines stretched for a mile long in some of its wealthiest states while US billionaires added $\$ 308$ billion to their coffers! And this when the pandemic may kill more of its citizens than all its wars of the twentieth century combined! In India, six weeks into a hastily imposed nationwide lockdown, when trains were finally organized to take migrant workers home, the Karnataka state government refused to let them go because construction companies were anxious not to lose their labor, effectively confining them to their jobs in serf-like conditions!

Without cross-class solidarities, a generalized retreat from globalization is not likely though some supply chains will necessarily be reorganized. 
The settle-at-home environment has exposed inadequate Wi-Fi coverage in countries where call centers are prevalent like the Philippines and India and this is likely to lead to the more extensive deployment of artificial intelligence (chat bots) and portend the repatriation of these operations to highincome states. When countries hijack PPE destined for others, a greater push for self-sufficiency in pharmaceuticals and medical supplies is inevitable, especially since China provided 42 percent of the world's PPE in 2018. Washington and Brussels would prefer to reduce their dependence on China but it would entail higher rates of taxation to build infrastructures and raise wages to enable consumption of more expensive goods - neither of which they have any appetite for as yet.

Supply chains in manufacturing cannot easily be reconfigured. Manufacturing depends on specialized suppliers who have built networks for ancillary parts and skilled labor and these are not easily substitutable. In just four weeks in February, Chinese factories ramped up their daily production of face masks from 10 million to 116 million and by early April they were exporting 4 billion masks and 2.8 million test kits. In contrast, not only could the US not similarly ramp up production but the White House is so distrusted by state governments that they are hiding their purchases of PPE from Washington! Beijing also rushed medical supplies to Italy and other southern and eastern European states when the European Union did not thereby fraying ties within the bloc even further than they already were.

Food shortages highlight the strategic significance of global supply chains. Regardless of their vital importance, governments in high-income states are unlikely to cut their domestic farm subsidies and their governments will almost certainly tie aid to client states' opening up their markets and compel them to cultivate out-of-season crops for northern consumers. Relatively higher wages in wealthier states will continue to draw migrant agricultural workers from their peripheries.

Just as they were during the deglobalization following the outbreak of the First World War, low-income states are enmeshed in links not of their making and primarily not to their benefit. They can break these shackles only if powerful movements - perhaps by their internal migrants evicted from their places of employment and their poor - establish local control over local resources as the Chiapas insurgency did when the North American Free Trade Agreement threatened their livelihoods.

NPT Editors: Professor Gürkaynak, can you comment on Prof. Palat's observation in the first round that the IMF should issue SDRs to lowand middle-income countries? What might we expect in terms of the world financial structure that he mentions? We would also like to ask you how the tension between the disruption of the global economy, and hence growth, and 
the demand for expanded social safety nets can be reconciled given the massive debt burden you raise in your contribution.

Refet Gürkaynak: The basic point I would like to make in this round is this: trickling down requires a large enough surplus at the top. In a prolonged period of low aggregate output that will not be the case. This applies internationally as well as intranationally. "There is less" is a statement about physics that, for a while, will have to be taken as granted. The distributional issue is a social and economic concern, which is bounded by the physical constraint. Trying new approaches to income generation and distribution is imperative and has to be done with the understanding that in the very near future most of what we will be doing through policy will be redistribution of a lesser output.

Before discussing the distributional issue, two notes are in order. One has to do with the nomenclature of aggregate economic pain. We are used to associating recessions with bad times and expansions with good ones. This is not quite correct. Recessions are times of declining aggregate economic activity. They tend to be quite short and the COVID recession, if one is in the books, will be particularly short. Economic activity will begin to pick up the moment countries begin to reopen. We will then be in an expansion but expanding from an exceptionally low base. Unemployment will remain high and output/income will remain low for quite some time. Thus, the end of the recession, as declared by the NBER Dating committee in the US and Euro Area Business Cycle Dating Committee (EABCDC) in the euro area will only mark the time of things no longer getting worse, but not designate the end of the pain. It is not the recession itself but its aftermath that has to be the main object of concern. (See the latest release of the EABCDC.) The recession can be blamed on the pandemic directly but there is no such external cover for policy makers in the expansion.

Second, the output loss is not completely exogenous. Countries have differing experiences based on their health systems and the precautions they took during the pandemic. They will have even more differing experiences postpandemic, based on how they choose to deal with debt and distributional issues. All countries will suffer in the aggregate but allowing the pandemic to provide fertile ground for larger firms to increase their market power will certainly make things worse and that is a policy choice. There are many such policy choices now.

Then again, the premise stands: there will be less. Internationally this means poorer, more indebted countries and especially those with less access to domestic finance and monetization will be looking for help from international organizations, in particular the IMF. And the IMF will not have enough to go around. The IMF is not a creator of funds; it is a distributor. No one 
transacts in SDRs, and creating more SDRs (which will require the IMF Board to approve the expansion) will help only of there are dollars that those SDRs can buy. An increase in the capital of the IMF would do that. But would the largest stakeholders of the IMF, who themselves are reeling from the effects of the pandemic, do that? And if they did, what would the effects be?

The effects are equivalent to increased policy stimulus globally, where the expansion is geared toward the poorer countries. Then again, there is physically less. So richer countries must be promising some of what they have to poorer countries. The political economy of this is not trivial and is not a matter that the IMF can decide. It is not about SDRs, but is about bread and medicine.

The same applies within countries as well. In an environment where there is physically less, one has to take from someone to give to someone else. This is very desirable based on social justice. The trickle down, that quite amazingly and often appallingly suffices in normal times and even normal high-unemployment periods, will not be the panacea this time. There just are too many people who will need the trickling down, from a smaller pool of income that can trickle down. We will see social and political repercussions of this within and across countries.

This is not to say that, given the physical constraint of lower aggregate income, there is nothing to be done. To the contrary, now is the time to be deliberate about redistribution and our social and economic organization. What we had before the pandemic was not an inevitable outcome and there is nothing inevitable about going back to it. Spain is experimenting with universal basic income. It can be done. Not even trying will lead to major social problems as the number of people who are lacking, and lacking for the first time, will be too high to ignore. And many of those people will not be as used to being ignored as those who were always at the bottom of the ladder. This too is the case within and across countries. Too many people with nothing to lose is not a sustainable equilibrium.

NPT Editors: Thank you all for the second round of answers. Analyzing your responses, we may tease out two major themes. One is the significance of political movements and policy making in bringing about different outcomes. The other is rising inequalities. Your responses also demonstrate that these themes play out at different scales: national and supranational (international or global). Your differences on the prospects of global leadership, a new international order, deglobalization, and regional or national variants of protectionism, we would argue, weave through the interactions of these themes and scales.

In your responses as well as in opinions expressed by other social scientists in various media, three potential trajectories for the post-COVID-19 world 
are put forth. We might take the liberty of paraphrasing these as (1) a return to business as usual, (2) fixing the existing system via introducing and implementing major or minor tweaks, and (3) a radical rupture, the direction of which is unclear.

Thinking about the themes and scales just mentioned, we would like to ask you the following in the third and final round: which one of these three trajectories is more likely, and in your opinion which one is more desirable? If you possibly can, we would also appreciate it if you reflect on Turkey or similar countries and/or regions in this context. Finally, you are welcome to engage with the second-round responses of the other participants.

Prof. Buğra, we would like to start with you. How would you respond to these questions? Specifically, what crucial role(s) could leadership or the lack thereof play?

Ayşe Buğra: I think the question can be answered only by considering alternative scenarios about possible developments in a number of areas and by raising other questions. This is what I will try to do by remembering some of the points made during the previous rounds of our debate.

As I mentioned before, there will be strong interests acting in the direction of returning to "business as usual." However, the problems created or revealed by the pandemic will require serious policy responses at national and supranational levels, and the tone of criticism from neoliberal globalization's discontents will be raised. Critical voices and arguments for alternative policy orientations, as well as protest movements of different types, will not be insignificant through the short-run policy interventions to deal with the decline of growth rates, the reduction in trade, mounting domestic and international debt, and rising unemployment, poverty, and inequality. The tension between the shortage of financial resources and the need for stronger safety nets will complicate the policy decisions to be made in the short run. At the same time, the reduction in trade and the protectionist reaction will reinforce each other in a vicious cycle. In such a setting, no matter how strong is the impulse to return to business as usual, the existing regulatory framework of production and distribution will need to be "fixed" and this will be difficult to do without addressing the roles that international organizations, G7 and G20 governments, and the EU should, could, or would play in the process. Questions of power and responsibility will emerge and the terms of international relations will no longer appear as given. There is, therefore, potential for transformation, if not a radical rupture. Whether this would be desirable or not would of course depend on the interface between the different forces shaping the process of transformation.

I find the leadership question important. International organizations which have the authority, resources, and legitimacy could play a meaningful role in 
global governance in conformity with Keynes's vision of the post-Second World War order. The Bretton Woods system was not in full conformity with Keynes's ideas and the institutional system which was restructured in the context of late twentieth-century globalization is even less capable of dealing with the current economic problems intertwined with political ones. The alternative could be the concerted action of powerful political actors such as the US and the EU to prevent the emergence of a dismal situation where the rise of inequality within and between nations would go together with the evolution of what we now call authoritarian populist regimes toward the historically familiar political forms of totalitarianism.

That is why I find the result of the coming American elections important since one would not hope to see the US playing a positive role in a situation of global crisis under Trump's presidency. I also think that a more cohesive European Union, which can overcome the discord among member nations and adhere to the principles of its Social Charter, could assume more responsibility at the level of international relations and have a significant moral and political influence.

An optimistic scenario of coordinated action by the US and the EU could involve at least some changes in the existing global framework of regulation of production and distribution. Certain crucial issues of contention could come on the agenda and be debated by allowing the progressive critiques of globalization to have voice and impact in the decision-making process. For example, the lessons from the pandemic could be interpreted in a way that supports perspectives on equal access to health as a social right; private funding of medical research could be contested in its implications for medical solidarity; there could be a thorough questioning of the current status of TRIPS (Trade Related Intellectual Property Rights) in vaccines and pharmaceutical drugs with their dire consequences in situations of health crisis, but also in "normal" times when many people lose their lives as a result of curable diseases. In a parallel vein, one could expect the current state of commercialized agriculture and the domination of the sector by agribusiness to be more intensely contested. It would of course be desirable to see a change in the policy environment in a direction where issues such as these are seriously addressed.

However, a discussion of the potential trajectories of the post-COVID-19 world should also include the position of the low- and middle-income countries. In these countries, the already present protectionist trends might become stronger with a new version of the old third-world nationalism as their supporting ideology. One could also imagine a multipolar world with China and/or Russia as economic and political poles of attraction for low- and middle-income countries, presenting to these countries an alternative to the model of global economic integration accompanied by political democracy. 
What then would be the position of Russia and China in the postpandemic world? In the short run, the state of the Chinese economy in particular will surely be a major issue in the global policy debate. What would be the impact of a decline in China's economic growth on the world-economy and global politics? Could the other countries' dependence on China for cheap imports and as an important export market be alleviated easily? If China becomes less important as a global economic actor, would this mean more opportunities for industrial growth and employment for other countries? An economically less vibrant and poorer China would also have fewer resources to have influence in global politics. Would this constitute a positive development in terms of democratization in middle- and low-income countries?

But I think that the underlying question, which remains relevant no matter which one of the possible scenarios is closer to the future of the world order, is the following: to what extent will institutional and policy diversity be tolerated and what will be the economic and political terms of coexistence within and between different countries?

NPT Editors: Thank you very much Prof. Buğra. Professor Keyder, we would now like to ask you the following: how do you think the experiences and status of the middle classes may change due to the pandemic?

Çağlar Keyder: The discussion on the distributional consequences of the pandemic has focused too readily on policies states may pursue in order to respond to unemployment and growing precarity. This, of course, is unavoidable as a measure addressing basic needs in the short term. Social policy that aims to redistribute incomes and maintain a basic standard of living is the immediate recourse in times of great need. It is, however, becoming clear that the epidemic might remain with us for longer than we hoped and may transform even more radically many of the basic practices that had ushered in "modern capitalism" between the end of the First World War and the last quarter of the twentieth century. Some of the adverse trends, incepted since the 1980s, are now attaining deeper traction. When there is such structural disruption that threatens to become permanent, social policy will grow less effective, and more of it will be required. The immediate concern, rather than bolstering social policy, should be to fight to rectify the institutions that have been under threat.

Much has been written on the declining share of labor, stagnant wages and secular unemployment, all of which have contributed to define the contours of capitalism since the neoliberal turn. There was, however, another feature of the golden age that made twentieth-century capitalism distinctive: the growth of a new middle class whose presence transformed the polarized capitalism of the previous century. This stratum, whose life chances improved due to education and training, fulfilled tasks that modern, organized capitalism required. 
They were able to base their bargain with capital on the cultural, organizational, and knowledge-intensive services they could provide. This bargain was successful beyond expectations in the post-1945 golden age as the middle class captured a larger share of incomes in advanced countries and could persuade states to invest in institutions (especially in education) that would extend their ascendancy. Neoliberal globalization put an end to this success story. It targeted not only the unionized working class but also the dominance of governmental practices that prioritized various middle-class concerns relating to science, administration, culture, and the environment. As states were made to withdraw funding from the most crucial institutions nourishing the middle class, commodification ran rampant and the middle classes were confronted with the difficulty of guaranteeing the cost of reproduction maintaining their family such that their children would be able to acquire similar cultural and educational benefits as their parents.

The capital of the middle class is cultural - primarily credentials in education. Significant accumulation in economic capital or property is rare; investment in children is in the form of tutors and crammers and exclusive schools, since there is faith that educational achievement will be rewarded. With the neoliberal turn, good education became forbiddingly expensive: public schools were deprived of funds, middle-class budgets were strained, and social mobility became less common. Avenues toward middle-class achievement were narrower. We have become accustomed to this gradual erosion of the opportunity scape. Yet the COVID-19 environment is set to strain what remains of the middle-class prospect even further.

In a brief six-month sprint, the epidemic has, perhaps irremediably, eroded the institutions dear to middle-class lives. Schools try hard to strike a course between lockdown and the demands of reopening. Most universities have devised ways of accommodating students that deprive them of the cherished campus experience. In primary and secondary schools as well, there will be recourse to online teaching some of the time. It is worse in crèches and day-care centers: in this pre-school experience that parents are most directly invested in, there are no solutions that satisfy. The overall situation is frustrating for parents and dispiriting for children. Many opt out to try homeschooling, or periods without formal education. Of course, maintaining children at home turns out to be costly, especially when one of the two incomes middle-class budgets require has to be relinquished. Under these constraints, it is not surprising that the decision to have children is fraught with uncertainty.

The cultural life available in urban environments has also been diminished, with the shared experience of museums, sports events, theatres, restaurants, bars and cafes, and even public transport now deemed risky. Of course, cities 
and urban life have historically been a privileged channel of middle-class progress - the path, through civil society, to participate in the political community. As urban life becomes suspect and less accommodating, especially to families with children, the acquisition of cultural accomplishments becomes problematic.

The point I am making is that while discussion and advocacy defending redistribution is fine and should certainly be pursued, the further erosion of institutions that were the foundation of a thriving middle class (and contributed to the achievement of an acceptable income distribution) threatens the fundamentals of a more desirable social order. States were complicit in the depletion of funds dedicated to education; now, under COVID-19, they submit to the exigencies of circumstance, and serve to further entrench the impoverishment of institutions providing public amenities and social goods.

NPT Editors: The policy and cultural outcomes of institutional erosion have so far emerged as key common threads in the third round. Prof. Palat, what is your take on these questions? We would also like you to comment on the potential role of social movements in the aftermath of the pandemic.

Ravi Arvind Palat: Economic crises typically spawn massive protest movements but the COVID-19 pandemic has been different. The lockdown or settle-at-home imposed by most governments to mitigate the spread of the virus gave police forces the license to clamp down on demonstrations.

Paradoxically, the pandemic registered itself in our consciousness precisely when a wave of protests was sweeping across the world. What was striking about many of these movements was that although they were triggered by a relatively minor issue - subway fares in Santiago, Chile, or proposed taxes on WhatsApp and VOIP phone calls in Lebanon, for instance - they snowballed to address the much larger issues of inequality and injustice. Despite attempts to corral these movements by minor concessions they continued virtually unabated till the pandemic-induced lockdown.

In the United States, during the 2020 election cycle, the Democratic Party establishment faced a grassroots challenge headed by Senator Bernie Sanders and Representative Alexandria Ocasio-Cortez, advocating universal singlepayer health care, higher marginal tax rates, free university education, and higher minimum wages. Here too, despite the uneven imposition of a lockdown, the pandemic put a virtual end to primary campaigns.

When protests reignited after the murder of George Floyd in Minneapolis in May 2020, they had a global resonance - Hindustan Unilever even removed "fair" from the "fair and lovely" advertising of its beauty products in India indicating not only widespread support for social justice and racial equality but 
also pent-up frustrations as the lockdown increased inequalities and pushed millions into poverty.

Demands for social justice and racial equality united the Democratic Party establishment with its erstwhile grassroots opposition, and even pushed Republican Senator Mitt Romney to the demonstrations while subsuming demands for universal health insurance and taxing the One Percent. Indeed, corporations were even quicker to jump on the bandwagon than politicians. Significantly, neither the Democratic Party leadership nor corporate titans embraced the Black Lives Matter movement's call to dismantle the increasingly militarized municipal police forces!

Corporations' nimble response to the protests is telling: their human resources departments can easily incorporate anti-racism into training modules and teach their employees to work cooperatively without practicing microaggressions. It is as Ross Douthat wrote in the New York Times, "it's just a novel form of Fordism, with white-fragility gurus in place of efficiency experts."

After all, the pulling down of Confederate statues is not likely to give the One Percent sleepless nights! Taking down the statue of Cecil Rhodes does not change the fact that Britain continues to have the upper hand in relationships with most of its former colonies. Corporate incorporation of some of the anti-racist rhetoric is certainly not intended to substantially address the wage gap between black and white men which is in the United States today about what it was in 1951 !

Moreover, the clampdown has itself aggravated problems, especially the issue of gender inequality. In many places, the lockdown has led to an increase in the incidence of domestic violence as women and children are confined to their homes, and often deprived of their phones. Migrant rights are being trampled on with less public scrutiny than ever before.

Nevertheless, even if some radical slogans are hijacked by the elite in the short term, the very fact that the pandemic surfaced at a time when seemingly small events set in train wide-ranging and sustained protests that addressed broader issues of inequality and social justice indicate that over the longer term these issues will reemerge, even though the conditions may have changed: working from home changes employment practices, reduces municipal tax bases, and reshapes urban formations; lockdowns propel the transition to increased automation of production and attendant changes in supply chains; high levels of unemployment bolsters demand for universal basic income, at least in high-income states; and online teaching accelerates the transformation of education while severely constraining the scope of student protests.

Crucially, how issues of inequality and social justice are resolved will depend on the agencies spearheading demands for radical change. Trade unions and social democratic parties had been at the forefront of the creation 
of welfare states but the decline of industrial production has undermined unions, and social democratic parties based on them have become cheerleaders for neoliberalism. The United States' faltering response to the crisis has fatally undercut its global leadership and there is no obvious successor waiting in the wings. Will green movements and radicalized, educated professionals succeed in mobilizing a broader segment of society for progressive change? Will the changed economic and social ecology lead to increasing ethnic conflicts, spurred on by authoritarian and populist politicians? While the shape of the future world order is indeterminate, it is clear that a major rupture is in the works in the medium term. What we can collectively do is to seek to shape its contours in a more egalitarian manner through new forms of global coordination of a commonwealth of progressive forces.

NPT Editors: Thank you for linking the already fragile political structure prior to the COVID-19 pandemic to its effects we are experiencing now. Prof. Pamuk, how do you think globalization and more specifically the Turkish economy will cope with the pandemic?

Şevket Pamuk: It has been two months since we began responding to the questions posed by the New Perspectives on Turkey editors. We have learned a good deal during this period about the health impact of the pandemic around the world and in Turkey. There is still a great deal of uncertainty, however, about the future course of the pandemic and its economic impact. In this third round, I will briefly add to my earlier remarks about the future of globalization and then focus on the impact, especially the economic impact, of the pandemic in Turkey.

It is clear that globalization as we experienced it during the last three decades will slow down if not collapse after the pandemic. At a minimum, national security concerns will play a greater role in shaping the value chains and patterns of international trade. Should we expect other changes in globalization? Globalization in recent decades has been driven to a large extent by the interests of large corporations and focused excessively on economic and financial dimensions while problems about the environment, climate change, and health, among others, could not gain traction. It will be difficult for this pattern to change without major domestic political changes in the United States and in Europe.

The rest of my comments will focus on Turkey. Perhaps not surprisingly, given Turkey's connections and location on the main arteries of international travel and economic flows, the pandemic spread to Turkey early in comparison to many other developing countries. Inside the country, Istanbul and other urban centers in the west experienced the pandemic much more strongly than the rest of the country. However, hospital and bed capacity turned out to be adequate thanks, in part, to the age structure of the population, and lockdown 
measures have been reasonably effective. As a result, the worst outcomes with respect to health have been avoided so far in the first wave.

Even if the health impact of the pandemic can continue to be contained, however, Turkey's economic problems in the era of the pandemic are likely to be more severe than those faced by many other developing countries. Clearly, Turkey's economic and fiscal capacities for dealing with the economic impact of the pandemic are not comparable to those of more developed countries. In addition, the pandemic arrived at a difficult time for Turkey. After strong growth in the early years of the Justice and Development Party (Adalet ve Kalkinma Partisi, AKP) government, Turkey's economy had been slowing down and accumulating problems for more than a decade. The transition to the one-man political regime, growing authoritarianism, the disappearance of the rule of law, and poor economic management had seriously weakened the economy well before the recession that began at the end of 2018 . Turkey's private sector as well as international investors had lost confidence in the economy some time ago.

The use of expansionary monetary and fiscal policy and the decline in foreign exchange reserves in recent years had already depleted much of the policy ammunition that could be deployed in response to the pandemic. In the near and medium term, economic stagnation in the European Union, which is the market for close to half of Turkey's exports, and the decline in tourism revenues will add to the early economic impact of the pandemic. Some have argued that Turkey stands to benefit from the shifts of some of the value chains away from China in the aftermath of the pandemic. However, Turkey's weaknesses in its transportation network and in the sectors with more advanced technologies suggest that the benefits to Turkey from the expected shifts away from China are likely to be limited.

Turkey's economy is likely to experience economic stagnation, higher rates of unemployment and underemployment (even if official statistics do not reflect them), and growing poverty especially in urban areas, not only during this calendar year but for longer periods. These economic difficulties are likely to add another layer of challenges to the long-term decline of AKP rule. It remains to be seen what these deteriorating economic conditions will mean for domestic politics and the declining popularity of the AKP. It also remains to be seen to what extent the opposition and local governments in the hands of the opposition will be able to rise up to the challenges posed by these difficult conditions. NPT Editors: Prof. Gürkaynak, we would also like you to comment on the prospects for the Turkish economy. Particularly, what sorts of policies should be implemented to limit the effects of the economic downturn?

Refet Gürkaynak: The world had major problems before COVID-19, from climate change to discrimination and many others. Many countries 
had problems of their own as well. Turkey is one of these, and the idiosyncratic Turkish problems will define the post-COVID-19 period here. The pandemic will be over, or we will learn to live with it. But employment will not come back, or not nearly to the extent that it had declined. Unsustainable policies will lead to increasingly palpable problems that will burst.

That moment, the bursting of the problems, arrived in Turkey two years ago but the global shock, the pandemic, made it difficult to disentangle the effects of global and idiosyncratic problems. When the whole world is talking about a problem, it is easy to believe and pretend that the whole world has the same problem. This happened in the Global Financial Crisis as well, but this is a bridge too far. We will have to reckon with the domestic policy mess and its outcomes. Returning to business as usual will not be possible because business as usual had become unsustainable a long time ago.

Turkey was already in an economic crisis before the pandemic and will still be in one when the health scare is no longer headline news. This is, more than anything, a crisis of governance and will have to be addressed. We need a framework for sensible, internally consistent policy making. Despite the novelty of that idea after a decade of self-contradictory, stop gap policies, this is not a revolutionary development. I expect a move toward policies and outcomes closer to those in the aftermath of the 2001 crisis: a reconstruction. This does not solve many of our problems, either, but makes things bearable for most people. That is clearly an improvement, but fundamental change will likely happen slowly, rather than with a rupture. People used to a particular mode of production and distribution do not change their behavior overnight.

Going back to the answer I provided to the first question, I still expect more demands for bailouts and household support, and grave debt problems, as a result of this. Countries that were doing better before the pandemic will handle this better; countries like Turkey that were already experiencing homemade problems will feel its effects even more. These painful outcomes will be decided by past choices and will not be preventable, but minimizing their destructive effects will be possible. Even that minimum will hurt. After the immediate crisis is contained, we will need direction.

The world was always unequal, and some countries were always particularly badly run. But inequality was not always this wide, policies were not always this bad. We have lived through better times and know that those are possible, even though they also leave a lot to be desired. Change will begin by moving in the right direction, not necessarily by getting everything right at once.

NPT Editors: We would like to thank all of you for your incisive insights about the prospects of the global political economy in the post-pandemic 
world. Although emphasizing different issues, your comments individually and taken together demonstrate the significance of global leadership and sound economic and social policy. But also, we see that progressive collective action also has a role to play in order to push those policies in more egalitarian directions. 